\title{
Impact of a Wastewater Treatment Plant Upgrade on Amphipods and Other Macroinvertebrates: Individual and Community Responses
}

\author{
Katharina Peschke ${ }^{1 *}$, Yvan Capowiez ${ }^{2}$, Heinz-R. Köhler ${ }^{1}$, Karl Wurm $^{3}$ and \\ Rita Triebskorn ${ }^{1,4}$
}

${ }^{1}$ Animal Physiological Ecology, University of Tübingen, Tübingen, Germany, ${ }^{2}$ INRA, UMR 1114, EMMAH, Site Agroparc, Avignon, France, ${ }^{3}$ GÖL Water Ecology Laboratory Starzach, Starzach, Germany, ${ }^{4}$ Transfer Center Ecotoxicology and Ecophysiology, Rottenburg, Germany

OPEN ACCESS

Edited by:

Alberto Tiraferri,

Polytechnic University of Turin, Italy

Reviewed by:

Simone Graça Pinto Varandas, University of Trás-os-Montes and Alto Douro, Portugal Edoardo Calizza,

Sapienza University of Rome, Italy

*Correspondence:

Katharina Peschke

Katharina.peschke@uni-tuebingen.de

Specialty section:

This article was submitted to Water and Wastewater Management,

a section of the journal

Frontiers in Environmental Science

Received: 08 January 2019 Accepted: 24 April 2019

Published: 17 May 2019

Citation:

Peschke K, Capowiez Y, Köhler H-R, Wurm K and Triebskorn R (2019) Impact of a Wastewater Treatment Plant Upgrade on Amphipods and Other Macroinvertebrates: Individual and Community Responses.

Front. Environ. Sci. 7:64. doi: 10.3389/fenvs.2019.00064
In the present study, we investigated the efficiency of additional wastewater treatment based on powdered activated carbon and its benefit for the ecosystem of a connected river system in the catchment area of Lake Constance, Southern Germany. We focused on the overall health status of gammarids and the integrity of the macrozoobenthic community. Samples were taken up- and down-stream of a wastewater treatment plant (WWTP), as well as before and after its upgrading. The investigations showed that both sex ratio and fecundity of gammarids, as well as the macrozoobenthic community were affected by the effluent prior to the WWTP upgrade. After the upgrade, gammarids from the downstream site did not differ any longer from those collected upstream of the WWTP with respect to the investigated health parameters. Furthermore, the overall number of taxa and, particularly, the number of sensitive taxa within the macrozoobenthic community downstream of the WWTP increased considerably. Therefore, we conclude that the additional treatment with powdered activated carbon was highly efficient to improve invertebrate health and community integrity.

Keywords: wastewater treatment, powdered activated carbon, gammarid species, macrozoobenthos, invertebrate health

\section{INTRODUCTION}

During the last decades, the occurrence of micropollutants including ingredients of, e.g., pharmaceuticals, pesticides or personal care products (Daughton and Ternes, 1999) in aquatic environments and their potential impact on biota has become a worldwide issue of scientific and public concern. Although their concentrations range only between a few $n g / L$ to several $\mu \mathrm{g} / \mathrm{L}$ (Daughton and Ternes, 1999; Triebskorn et al., 2013a; Luo et al., 2014), they have been reported to be responsible for adverse effects in exposed aquatic organisms (Schirling et al., 2005b; Ladewig et al., 2006; Bundschuh and Schulz, 2011a; Schneider et al., 2015; Vincze et al., 2015; Triebskorn, 2017). Effluents from wastewater treatment plants (WWTPs) are known as major point sources for the release of micropollutants into the water cycle (Triebskorn, 2017; Villa et al., 2018). This is due to the fact that municipal WWTPs have mainly been designed to eliminate particular matter and nutrients, whereas the removal of micropollutants was not in the particular focus in the past. As a consequence, the removal of micropollutants is often insufficient or even completely lacking (Luo et al., 2014). One possibility to improve micropollutants reduction in WWTPs is an upgrade 
with additional treatment steps like ozonation or activated carbon (Bundschuh and Schulz, 2011a; Henneberg and Triebskorn, 2015; Thellmann et al., 2017; Giebner et al., 2018). In the present study, the influence of a WWTP upgrade with an additional purification step on the macroinvertebrate community was investigated. The study was conducted in the area of Lake Constance, Southern Germany, which serves as a major drinking water reservoir. The focus was on two major tributaries of Lake Constance: the river Schussen as a model stream located in a densely populated catchment area, and the river Argen representing a less anthropogenically influenced reference stream (Triebskorn and Hetzenauer, 2012). At the Schussen, the largest WWTP (Langwiese, AZV Mariatal) which treats about $50 \%$ of the wastewater of the catchment area has been upgraded with an additional powdered activated carbon stage in September 2013. Chemical analyses of more than 150 micropollutants showed that the additional powdered activated carbon stage was highly efficient in reducing the concentrations of micropollutants in the effluent and also in the surface water downstream the WWTP (Scheurer et al., 2017a). The present study focuses on assessing the overall health status of gammarids abundant in the two streams and the integrity of the macrozoobenthic community in the Schussen prior and subsequent to the WWTP upgrade and, in parallel, in the Argen as a control river which was not influenced by this measure. In the first part of our study we investigated the health of gammarids as important representatives of freshwater ecosystems (Schirling et al., 2005b). Due to their diverse diet (detritus, aufwuchs, carrion, and small invertebrates), their broad distribution, high biomass, short generation time, and high productive rates, gammarids are highly important for aquatic ecosystems (Pöckl, 1993a; Brehm and Meijering, 1996), also acting as shredders of plant material (Schwoerbel, 1999). Furthermore, they are an important part of aquatic food webs, particularly as food sources for fish (Meijering and Pieper, 1982). As gammarids are known for their high sensitivity to pollutants, they are regarded as suitable monitoring organisms for ecotoxicological studies (Schirling et al., 2005b; Ladewig et al., 2006; Bundschuh and Schulz, 2011a). In the present study, we used different methods to investigate the physiological status of gammarids from the biochemical to the individual level: analyses of the heat shock protein Hsp70 level, determination of fecundity in females, sex ratio in gammarid populations, and distribution of different gammarid species at the sampling sites. These analyses contributed to an evaluation of potential toxic and endocrine effects caused by the WWTP effluent. Although numerous studies already have focused on gammarids as indicators for adverse ecosystem effects caused by WWTP effluents (Gross et al., 2001; Schirling et al., 2005a,b; Ladewig et al., 2006; De-La-Ossa-Carretero et al., 2012; Schneider et al., 2015), until now, investigations using gammarids in the context of a WWTP upgrade are still very rare. Only two studies from Bundschuh and Schulz (Bundschuh and Schulz, 2011a,b) deal with the effects of an additional ozonation-based treatment step on gammarids with respect to alterations in feeding rates and population sizes. In these studies, the authors concluded that ozonation is an appropriate tool that contributed to the improvement of gammarid health in wastewater influenced rivers and streams. With our study, we further investigated the efficiency of activated carbon in eliminating micropollutants on the basis of gammarid health prior to and after the WWTP upgrade. Furthermore, we extended our view to the entire macrozoobenthic community which is commonly assessed in the context of the European Water Framework Directive (WFD) (European Comission, 2000). Although the composition of macrozoobenthic communities can be influenced by numerous stressors including, e.g., pesticides or organic pollutants (Berenzen et al., 2005; Bonzini et al., 2008; Adámek et al., 2010), there is, to the best of our knowledge, no study which has investigated the success of an additional powdered activated carbon treatment step with respect to the macroinvertebrate fauna, until now. Thus, the objective of the current work is to evaluate the impact of a WWTP upgrade on both individual health of gammarids and, in addition, the integrity of the macroinvertebrate community.

\section{MATERIALS AND METHODS \\ Location and Description of Sampling Sites}

The study was conducted at the Schussen river, a major tributary to Lake Constance in Southern Germany, which is influenced by effluents of 20 WWTPs and more than 100 stormwater overflow basins (SOBs) (Triebskorn et al., 2013a). The focus of the study was on the WWTP Langwiese (N47 $44^{\prime} 53.22^{\prime \prime}$, E9 $\left.9^{\circ} 34^{\prime} 35.49^{\prime \prime}\right)$, one of the major WWTPs connected to the Schussen river and upgraded with a powdered activated carbon stage in September 2013. Location and sampling sites are shown in Figure 1. Sampling sites S 0, S 1, S 2, and S 3 were located at the Schussen river. S 0 (N47 $45^{\prime} 29.59^{\prime \prime}$, E9 $\left.{ }^{\circ} 35^{\prime} 22.88^{\prime \prime}\right)$ was located $2.5 \mathrm{~km}$ upstream of the WWTP Langwiese as well as $150 \mathrm{~m}$ upstream of the SOB Mariatal, S 1 (N47 $40^{\prime} 19.57^{\prime \prime}$, E9 ${ }^{\circ}$ $\left.32^{\prime} 06.20^{\prime \prime}\right)$ was situated $1.12 \mathrm{~km}$ downstream of the SOB Mariatal and $630 \mathrm{~m}$ upstream of the WWTP, S 2 (N47 $44^{\prime} 42.27^{\prime \prime}, \mathrm{E}^{\circ} 33^{\prime}$ $\left.45.04^{\prime \prime}\right)$ was located $850 \mathrm{~m}$ downstream of the WWTP and S 3 $\left(\mathrm{N} 47^{\circ} 39^{\prime} 16.20^{\prime \prime}, \mathrm{E}^{\circ} 31^{\prime} 52.93^{\prime \prime}\right)$ was located $15 \mathrm{~km}$ downstream of the WWTP. Sampling sites S $4\left(\mathrm{~N} 47^{\circ} 44^{\prime} 20.46^{\prime \prime}\right.$, E9 ${ }^{\circ} 53^{\prime}$ $\left.42.78^{\prime \prime}\right)$ and $\mathrm{S} 5\left(\mathrm{~N} 47^{\circ} 36^{\prime} 09.71^{\prime \prime}\right.$, E9 $\left.{ }^{\circ} 34^{\prime} 01.91^{\prime \prime}\right)$ were situated at the Argen river. This river served as a less polluted reference site (Triebskorn and Hetzenauer, 2012). Sampling of gammarids took place at S $0, S 3$, and S 5, whereas the macrozoobenthic community was investigated at sites $\mathrm{S} 0, \mathrm{~S} 1, \mathrm{~S} 2, \mathrm{~S} 3$, and $S$ 4. As the results obtained for the gammarid investigations should be comparable to results gained from diverse analyses with feral fish conducted by other partners within the project our study was embedded in (SchussenAktivplus) (Triebskorn et al., 2013a; Henneberg et al., 2014; Henneberg and Triebskorn, 2015; Maier et al., 2015, 2016), fish and gammarids were caught simultaneously at the same sites at the Schussen river, at sites $S$ 0 and S 3. S 0 was chosen as a sampling site upstream of the WWTP. In order to make sure that fish, caught downstream of the WWTP, did not have migrate upstream the WWTP, sampling of fish exclusively took place $15 \mathrm{~km}$ downstream of the WWTP (S 3 ). We refrained from sampling site $S 2$, because it was too close to the WWTP allowing fish to migrate up- and down-stream 


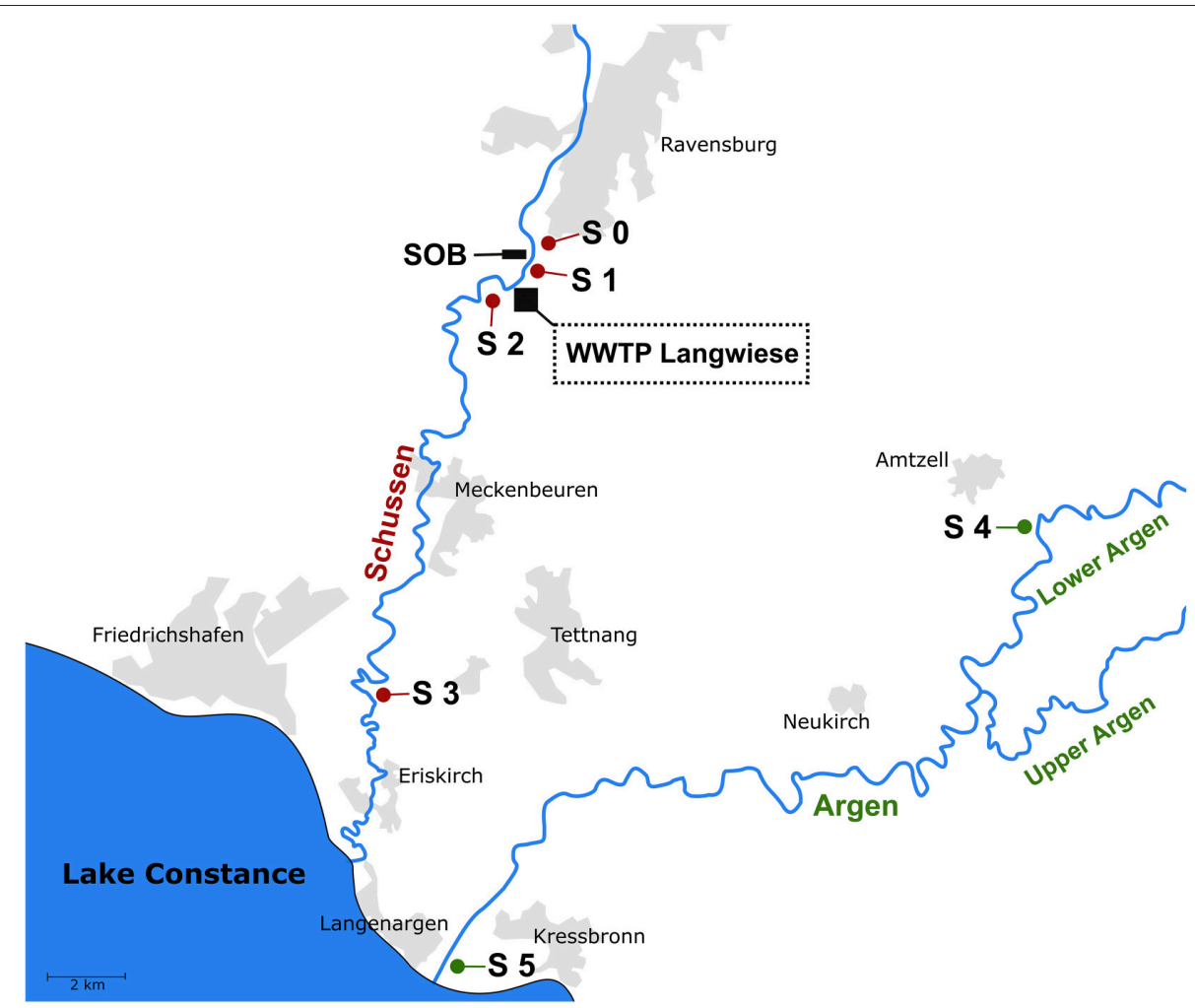

FIGURE 1 | Sampling sites at the Schussen and the Argen river, two tributaries to Lake Constance. Gammarids were collected at sampling sites S 0, S 3 , and S 5. Macrozoobenthos was sampled at sampling sites S 0, S 1, S 2, S 3, and S 4. WWTP, wastewater treatment plant Langwiese (AZV Mariatal); SOB, stormwater overflow basin Mariatal. For exact coordinates of sampling sites see chapter 2.1. The map is based on OpenStreetMap. Map data: ( O)penStreetMap contributors, license: (http://opendatacommons.org/licenses/dbcl/1.0/).

of this site. In contrast, macrozoobenthos is almost stationary (Langmaier, 2006; Di Lascio et al., 2013), hence, short distances between different sampling sites is not an issue. Thus, to get information on changes within the macrozoobenthic community along the course of the Schussen with higher spatial resolution, two additional sampling sites were included: $S 1$ was downstream of the SOB but upstream of the WWTP, whereas S 2 was $850 \mathrm{~m}$ downstream of the WWTP.

\section{Studies With Gammarids}

The gammarid studies were conducted prior to and after the WWTP upgrade with a powdered activated carbon stage. At each site, animals were sampled up to four times per year resulting in a large data set which enabled the differentiation between effluent-dependent effects on the one hand, and seasonal or annual influences on the other hand. Prior to the WWTP upgrade, samples were collected in 2010 (April 19, June 29, August 19), 2011 (May 9, July 7, September 2, October 28), and 2012 (May 3, July 4, October 24). After the upgrade, gammarids were sampled in 2014 (May 21, July 1, October 2), 2015 (May 30, August 12), 2016 (May 3), and 2017 (May 18). Gammarids were pick-sampled at typical habitats such as roots, macrophytes, and conglomerations of leaves. Using a conventional sieve (mesh site $1 \mathrm{~mm}$ ), 180 gammarids were collected at each site and sampling occasion and were stored together in a container. For each of the following investigations, the required number of gammarids was randomly taken from this container.

\section{Distribution of Species and Sex Ratio}

For species and sex determination, 100 gammarids per site were chemically fixed with $2 \%$ glutardialdehyde (dissolved in $0.005 \mathrm{M}$ cacodylate buffer) and examined under a stereomicroscope. Based on external morphological characteristics, the two gammarid species (Gammarus roeseli and Gammarus pulex), abundant in the Schussen and Argen rivers, could be distinguished. In $G$. roeseli, the carapax in the abdominal dorsal region of the body shows spine-like processes, while G. pulex does not show such morphological features (Pöckl, 1993a). The sex of each individual was determined based on secondary sexual characteristics. Thus, female gammarids were characterized by four pairs of oostegites (brood plates) and males by two genital papillae on the ventral body side (Welton, 1979). Since external sexual organs are not developed until the ninth molt, small gammarids (body length $<6 \mathrm{~mm}$ ) were determined as “juvenile” (Pöckl, 1993a). 


\section{Fecundity}

For determination of the fecundity, per site twenty breeding females were randomly selected from the sample container. Each breeding female was fixed separately in $2 \%$ glutardialdehyde (dissolved in $0.005 \mathrm{M}$ cacodylate buffer) and examined using a stereomicroscope. The species of every breeding female was determined and the body length (distance from the anterior margin of the cephalothorax to the posterior margin of the telson) was measured on graph paper. Using dissecting needles, the marsupium was opened gently, and eggs and juveniles were retrieved and counted. Afterwards, the fecundity index (FI) was calculated as follows: FI = number of eggs or juveniles/body length of breeding female (Pöckl, 1993b; Pöckl et al., 2003).

\section{Hsp70 Quantification}

For the quantification of stress proteins (Hsp70), per sampling site 20 praecopula pairs (one male and one female gammarid) were picked randomly from the sample container. The exclusive use of praecopula pairs overcomes the problem of varying Hsp70 levels in different reproductive stages (Schirling et al., 2005a). In addition, the sex of the gammarids could easily be determined in the praecopula stage, since the males always hold the top position (Borowsky, 1984). Consequently, the Hsp70 level was analyzed in each sex separately. According to Sures and Radszuweit (2007) and Sures (2008) who found adversely affected stress protein expression in gammarids infected with Acanthocephala, we only used visibly uninfected gammarids. Analyses of Hsp70 level were carried out as described by Peschke et al. (2014). Analyses were conducted in whole body homogenates, and the determination of the total protein content of the samples was carried out according to Bradford (1976). SDS-PAGE was run to separate standard amounts of total protein. By semi-dry blotting, proteins were transferred to a nitrocellulose membrane. After two steps of antibody incubation (first: mouse antihuman hsp70 monoclonal antibody; second: goat anti-mouse IgG $(\mathrm{H}+\mathrm{L})$ antibody, both: Dianova, Hamburg, Germany), the Hsp70-antibody-complex was visualized using chloronaphthol. After digitalization, the optical volume (gray scale values $x$ area) of the protein bands was quantified by densitometric image analysis (Image Studio Lite, 4.0.21, LI-COR Inc.). An internal standard, serving as a reference, was run in parallel on each gel.

\section{Integrity of the Macrozoobenthic Community}

Alike the investigations on gammarids, the macrozoobenthic community was studied prior to and after the WWTP upgrade. Prior to the upgrading, the macrozoobenthic organisms were sampled in 2012 (April 29, October 6) and 2013 (May 20, October 9). After the upgrade, samples were collected in 2014 (April 11, October 4), 2015 (June 11, October 3), and 2016 (July 9, October 8). On site, the macrozoobenthic organisms were collected by means of the multi habitat sampling method according to the protocol of the European Water Framework Directive 2000/60/EC (European Comission, 2000), using a Surber Sampler with a mesh size of $500 \mu \mathrm{m}$. After sampling, macrozoobenthic individuals were fixed in $80 \%$ ethanol. Subsequently, taxonomic determination in the laboratory was accomplished at least up to the level of the operational taxa list for German rivers (Haase et al., 2004). The ecological quality of the two rivers was determined by means of the evaluation software ASTERICS (AQEM/STAR Ecological River Classification System 4.04) including the German system PERLODES.

\section{Data Analyses and Statistics}

Gammarid species distribution: The differences among data for the different sampling sites were analyzed by a chi-squared test (Fisher's exact test following a sequential Bonferroni-Holm correction). The statistical significance level was set to $p<$ 0.05 . Sex ratio: The ratio of male to female gammarids was calculated for each sampling site. Each ratio was analyzed for a significant deviation from a 1:1.5 ratio using a Likelihood-ratio $\chi^{2}$ test following a sequential Bonferroni-Holm correction. The statistical significance level was set to $p<0.05$. This procedure is based on investigations of Ladewig et al. (2006) who reported the ratio of male to female gammarids differs from 1:1 in clean or only marginally polluted rivers and streams and showed a male to female ratio of 1:1.5 in a minor polluted stream in Germany. Based on these results, we assigned effects to be caused by the effluent of the WWTP in cases of significant deviation from a male to female ratio of 1:1.5 in favor of females. In a next step, the difference between the sex ratio at site S 0 upstream of the WWTP and site S 3 downstream of the WWTP was calculated as $\Delta \mathrm{S} 3-\mathrm{S}$ 0. By using TableCurve 2D (Systat Software Inc.) non-linear regression analysis was conducted for the $\Delta$ S 3-S 0 data prior to and after the WWTP upgrade. Fecundity: Following Pöckl (1993a), data obtained for breeding females of different species from the same site were pooled. In order to show differences between the sampling sites, the entire data set was statistically analyzed as follows: The data set was checked for normal distribution and homogeneity of variances. If both criteria were met, data from different sampling sites were compared with a one-way ANOVA linked to a Tukey-Kramer post hoc test. In case of normal distribution with inhomogeneous variances, a non-parametric Welch's $t$ test followed by a sequential Bonferroni-Holm correction was applied. If data were not normally distributed but variances were homogenous, a Kruskal-Wallis test with a Steel-Dwass post hoc test was performed. The statistical significance level was set to $p<0.05$. Hsp70: Differences between data for the respective sampling sites were statistically analyzed as described above for the fecundity data. All statistical analyses were conducted using the software JMP (SAS Institute Inc., version 14.0.0). Integrity of the macrozoobenthic community: To determine potential effects of the WWTP's upgrade, we performed ANOSIM (analysis of similarities) using the Bray-Curtis dissimilarity measure on square root transformed data. ANOSIM were conducted on datasets either including or omitting data from sampling site S 4 (Argen river, reference stream). In order to show the results in a graphical way, we performed NMDS (non-metric multidimensional scaling). Both methods were conducted using $\mathrm{R}$ (version 3.5.2). 


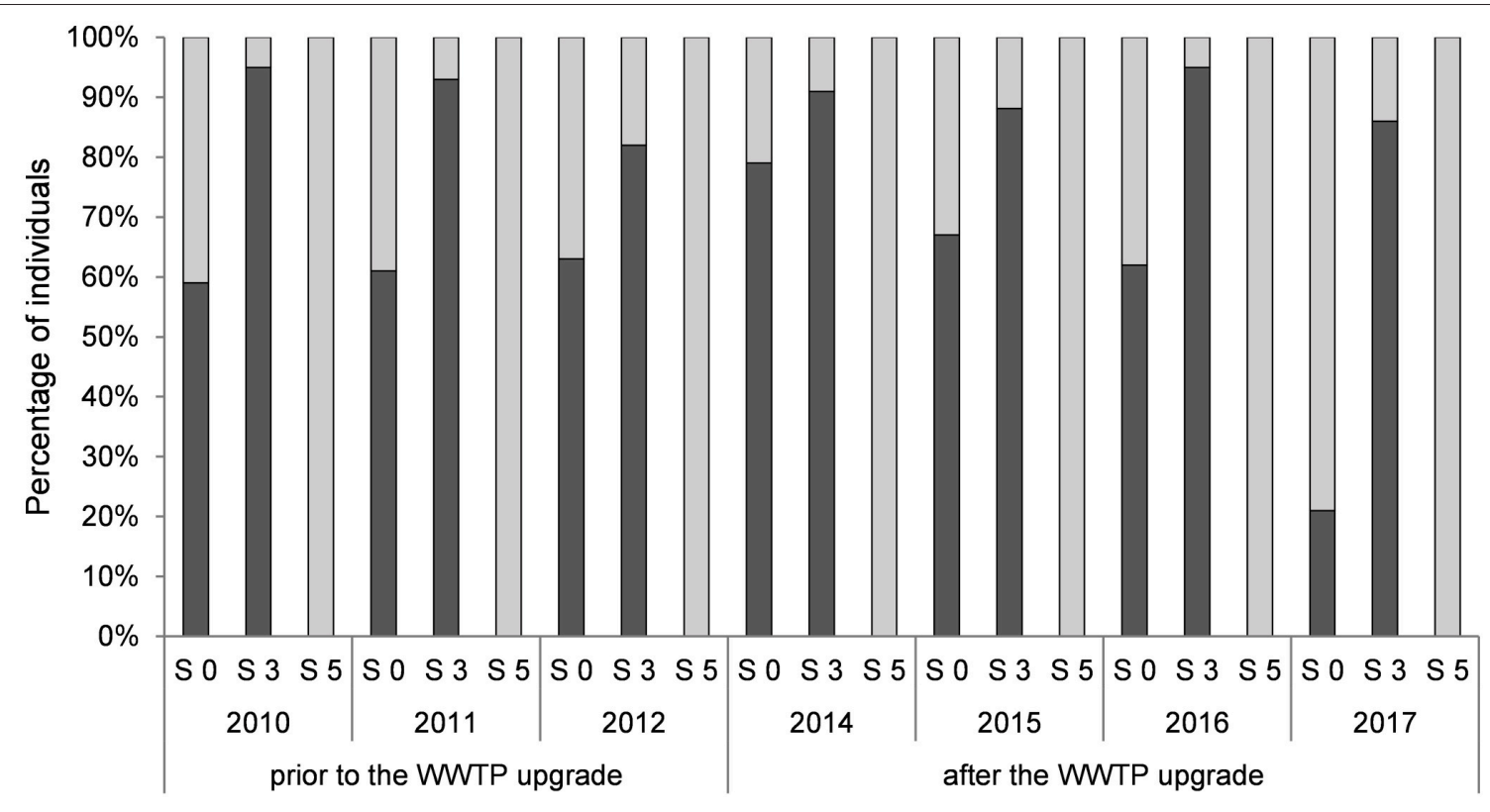

$\square$ G. roeseli $\square$ G. pulex

FIGURE 2 | Distribution of gammarid species prior to (2010-2012) and after (2014-2017) the wastewater treatment plant (WWTP) upgrade. Sampling sites at the Schussen river: S 0 upstream of the WWTP, S 3 downstream of the WWTP. Sampling site S 5 at the river Argen. Number of individuals at each sampling site is totalized for every year under investigation. Sample sizes in 2010, 2011, 2012, and 2014 at every sampling site: 300. Sample sizes in $2015: 200$ at each sampling site. Sample sizes in 2016 and 2017 at each sampling site: 100. Statistically analyzed: Fisher's exact test following sequential Bonferroni correction. Significant differences: 2010 S 0-S $3(p=0.0001)$, 2011 S 0-S $3(p=0.0001)$, 2015 S 0-S $3(p=0.0004)$, 2016 S 0-S $3(p=0.0001)$, 2017 S 0-S 3 ( $p=0.0001)$. S 0 2017 significantly different to $\mathrm{S} 0$ in 2016, 2015, 2014, 2012, 2011, and 2010 with every $p=0.0001$ (not marked in the graph).

\section{RESULTS AND DISCUSSION}

\section{Studies With Gammarids \\ Species Distribution}

Distribution of gammarid species varied between sites $S 0$ (upstream of the WWTP) and S 3 (downstream of the WWTP) within the Schussen river, as well as between the rivers Schussen and Argen. In the Argen river (S 5) only G. pulex was found within the time of investigation (Figure 2). In contrast, two gammarid species, G. pulex and G. roeseli, were collected in the Schussen river. The distribution of species differed significantly between sampling sites upstream and downstream of the WWTP. At S 0 (upstream of the WWTP), significantly more G. pulex and fewer G. roeseli were present compared to $\mathrm{S} 3$ (downstream of the WWTP). This held true for the investigation time prior to the WWTP upgrade, as well as subsequent to it. In general, both gammarid species prefer slowly running waters (Schwab, 1995) but G. pulex is more dominant in habitats with higher flow rates like in upper stream or spring sections (Pöckl and Humpesch, 1990). Thus, the dominance of $G$. roeseli at sampling site S 3 at the Schussen could be due to the rivers' morphology as the investigated sampling site is located at the lower section of the Schussen. In the Argen, the presence of G. pulex likely goes hand in hand with better water quality (Schwab, 1995). Given that there were no changes in species distribution downstream of the WWTP after the upgrade compared to the prior situation, we conclude that the effluent did not directly influence the occurrence of gammarid species at this sampling site.

\section{Sex Ratio}

Due to unequal frequency of gammarid species distribution, G. pulex and G. roeseli were examined together as G. spec for calculating the sex ratio. The number of G. pulex at $S 3$ was too low to reliably determine the sex ratio in this species separately. As a compromise, we examined G. pulex and G. roeseli together as G. spec. In order to examine potential effects of the WWTP effluent on the population structure at the downstream site, the ratio of male to female gammarids for each sampling site was calculated (Table 1). Studies from Ladewig et al. (2006) showed a male to female ratio of 1:1.5 in a minor polluted stream in Eastern Germany. As well, Welton (Welton, 1979) showed in her study that the sex ratio in gammarid populations in a minor polluted stream was not fixed to a ratio of 1:1 (male:female). According to Ladewig et al. (2006) she also determined shifted sex ratio in favor of females (Welton, 1979). Based on these results, the sex ratio in general should be regarded as to be affected whenever the ratio of male to female gammarids significantly differs from a 1:1.5 ratio toward females. Prior to the WWTP upgrade, we found a significantly shifted sex ratio toward females at S 3 (downstream of the WWTP) in spring 2010, 2011, and 2012, as well as in summer 2010. Subsequently to the upgrade, the sex ratio at S 3 was significantly shifted toward females in spring 2014 and 2015, only. However, in spring 2016 and 2017, 3 and 4 years after the upgrading, the sex ratio was not shifted toward more females downstream of the WWTP anymore. The presence of xenoestrogens can lead to a shifted sex ratio toward more females, as shown by Watts et al. (2002) in laboratory studies. 
TABLE 1 | Ratio of male to female gammarids in spring, summer, and autumn prior to (2010-2012) and after (2014-2017) the wastewater treatment plant (WWTP) upgrade.

\begin{tabular}{|c|c|c|c|c|c|c|c|c|c|}
\hline & \multicolumn{3}{|c|}{ Spring } & \multicolumn{3}{|c|}{ Summer } & \multicolumn{3}{|c|}{ Autumn } \\
\hline & S 0 & S 3 & S 5 & S 0 & S 3 & S 5 & S 0 & S 3 & S 5 \\
\hline 2010 & $1: 1.04$ & $1: 2.52^{*}$ & $1: 1.16$ & $1: 1.54$ & $1: 4.00^{*}$ & $1: 1.39$ & $1: 1.04$ & 1:1.66 & $1: 1.17$ \\
\hline 2011 & $1: 1.45$ & $1: 2.63^{\star}$ & $1: 2.81$ & $1: 2.25$ & 1:1.87 & $1: 1.71$ & $1: 1.26$ & 1:1.33 & $1: 1.24$ \\
\hline 2012 & $1: 1.21$ & $1: 2.27^{*}$ & $1: 1.78$ & $1: 1.73$ & $1: 1.46$ & $1: 1.67$ & $1: 1.16$ & $1: 1.51$ & $1: 1.20$ \\
\hline
\end{tabular}

WWTP upgrade

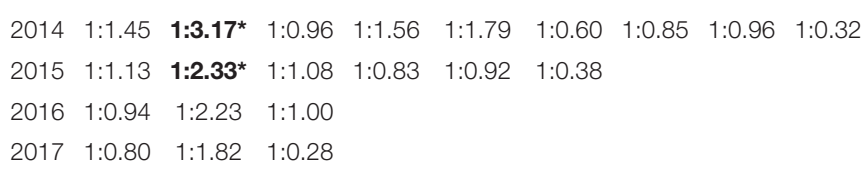

Sampling sites at the Schussen river: S 0 upstream of the WWTP, S 3 downstream of the WWTP. Sampling site $S 5$ at the river Argen. Statistically analyzed for shifted ratio toward females (= more than ratio of 1:1.5): Likelihood-ratio $\chi^{2}$ test following a sequential Bonferroni-Holm correction. Significant shifts toward females are marked in bold and with asterisks. Spring: S $32010 p=0.0185$, S $32011 p=0.0100, S 32012 p=0.0041, S$ $32014 p=0.0009$, S $32015 p=0.0377$. Summer: $S 32010 p=0.0001$.

After 100 days of exposure to $100 \mathrm{ng} / \mathrm{L} 17 \alpha$-ethinylestradiol, the sex ratio in evenly distributed populations $(1: 1)$ switched to a 1:2.7 ratio (males: females) (Watts et al., 2002). On the basis of an E-Screen cell proliferation assay, Kuch (2017) detected 0.4 ng/L EEQ (estradiol equivalent concentration) at sampling site S 3 in the Schussen river downstream of the WWTP prior to the upgrade. Even though this concentration is much lower than the ethinylestradiol concentration used by Watts et al. (2002), it has to be taken into account that gammarids sampled in the field are permanently exposed to xenohormones. Therefore, even lower ethinylestradiol concentrations might have resulted in the shifted sex ratio toward more females downstream of the WWTP (S 3) prior to the upgrade. Flow channel experiments from Schneider et al. (2015) have shown corresponding effects regarding the sex ratio in gammarids. Using four flow channel systems, they exposed individuals of $G$. pulex to different concentrations of a WWTP effluent over a period of 30 days. They observed a shift in the sex ratio in favor of females with increasing wastewater concentrations (Schneider et al., 2015). In the Schussen river, after the upgrade of the WWTP, EScreen assays showed significantly lower EEQs at field sites downstream of the WWTP compared to the situation prior to the upgrade (Kuch, 2017). Furthermore, determination of EEQs in wastewater samples from WWTP Langwiese taken subsequently to several cleansing steps showed a reduction of EEQs of $86 \% \pm 5 \%$ after powdered activated carbon and flocculation filtration compared to the secondary clarifying step (Kuch, 2017). Consequently, the reduction of EEQs in the WWTP effluent led to lower EEQs at the sampling sites downstream of the WWTP, which is mirrored in the sex ratio of feral gammarid populations.

In order to visualize differences between the sampling sites $\mathrm{S}$ 3 and S 0 with respect to the sex ratio, a non-linear regression analysis using a Fourier polynomial $7 \times 2\left(r^{2}=0.98\right)$ was performed (Figure 3). Prior to the WWTP upgrade, large deltas between S 3 and S 0 were found, particularly in spring and early summer. At those time points, the sex ratios at $S 3$ showed a stronger shift in favor of females compared to $S$. However, also after the upgrade deltas between S 3 and S 0 were found in spring. This might be due to the fact that sampling site $S 3$ is not only influenced by the WWTP effluent but also by agricultural activities. To the best of our knowledge, agricultural practices and the use of pesticides have not changed during the period of our investigations in the area of S 3. Therefore, also pesticides with estrogenic potential and which are mostly used in spring may have influenced females at S 3 in spring and early summer. However, due to reduced EEQs in the effluent (Triebskorn, 2017) the differences with respect to the sex ratio between S 3 and S 0 continuously decreased after the WWTP upgrade. Thus, it is very likely that differences between S 3 and S 0 regarding the sex ratio in spring and early summer after the WWTP upgrade are mainly caused by pesticide application in springtime.

\section{Fecundity}

Pöckl (Pöckl, 1993a) showed that the fecundity index in equally sized females of different European Gammarus species is almost identical which allowed us to pool data obtained for G. pulex and $G$. roeseli in respect to calculate fecundity indices. Prior to the WWTP upgrade, fecundity indices in breeding females of autumn samples were significantly lower at S 3 (downstream of the WWTP) compared to the upper site S 0 in 2010, 2011, and 2012 (Figure 4). In autumn 2014, after the WWTP upgrade, the fecundity index downstream of the WWTP did not differ from the upstream sampling site any more. The same pattern was observed in spring and summer samples. Despite lacking significance, a distinct trend toward decreased fecundity indices downstream of the WWTP (S 3) compared to the upper site was detected. As observed for the autumn samples, these differences did not longer occur after the WWTP upgrade. Regarding the comparison of sampling sites at the Schussen river to $S 5$ at the Argen, differences with respect to the fecundity index in breeding females were obvious. In 2010, the fecundity index at S 3 at the Schussen was significantly lower compared to $S 5$ at the Argen. In 2011 and 2012, no differences occurred between S 3 and S 5 but the fecundity indices at $S 5$ were found to be significantly lower compared to S 0. Investigations in 2014 after the upgrade showed a significantly higher fecundity index at S 5 at the Argen river in comparison to both sampling sites at the Schussen. These results are corroborated by physico-chemical data for the respective sampling sites prior to and after the WWTP upgrade which have been assessed according to the protocol of the European Water Framework Directive 2000/60/EC (European Comission, 2000). With respect to this, the water quality of the Argen can be classified as "very good" whereas the water quality of the Schussen has to be classified as "good" (Maier et al., 2015; Peschke and Triebskorn, 2017). Also micropollutant analyses conducted in parallel showed that the Argen river is less polluted with chemicals than the Schussen, but, however, cannot be classified as completely "unpolluted" (Triebskorn et al., 2013b; Scheurer et al., 2017b). Diverging differences in fecundity indices between Schussen and Argen as observed in our study can also be seen as 


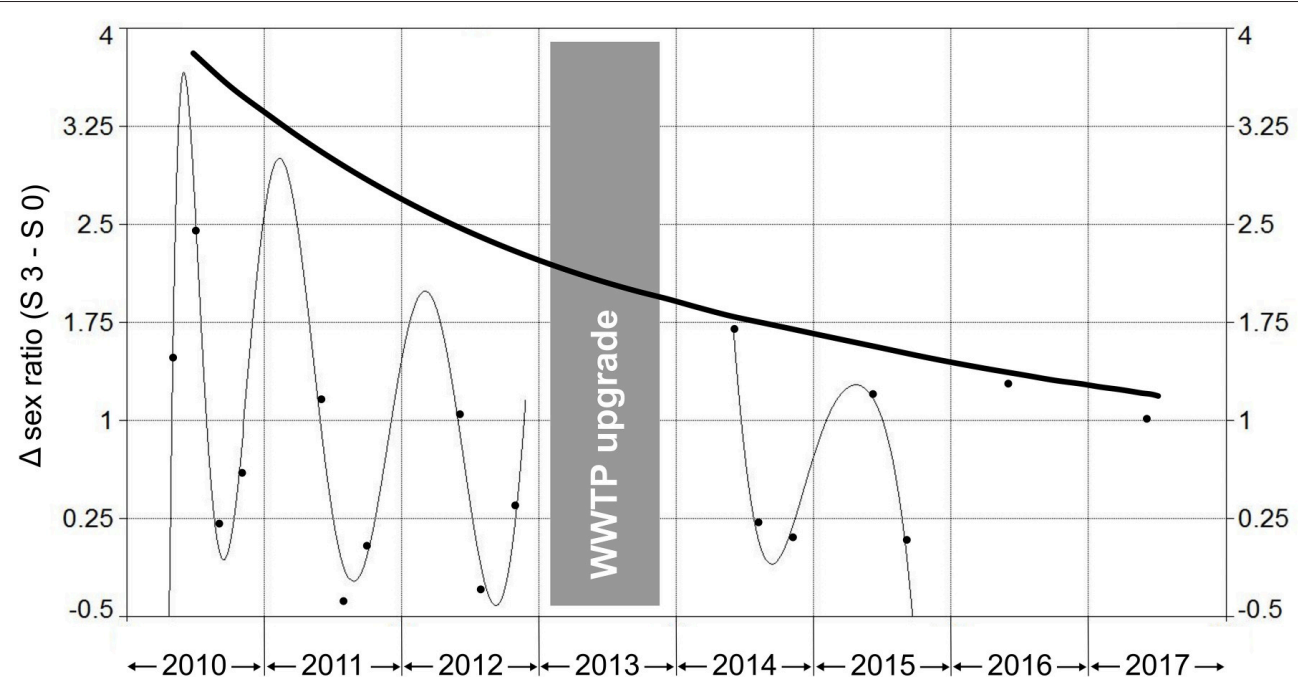

FIGURE 3 | Differences between sex ratio at sampling site S 3 (downstream of the WWTP) and S 0 (upstream of the WWTP) prior to (2010-2012) and after (2014-2017) the upgrade. Non-linear regression analysis by Fourier series polynomial $7 \times 2\left(r^{2}=0.98\right)$.

further indicators for the need to investigate the Argen river more in-depth as already recommended by Triebskorn et al. (2013b). However, the results obtained for the Argen river in this study can be used to detect inter-annual variation in the entire area and, thus, are mandatory for the interpretation of temporal differences between the sampling sites at the Schussen river. Prior to the WWTP upgrade (2010, 2011, and 2012), fecundity indices at S 0 , as well as at S 3 were significantly higher compared to the situation in 2014 after the WWTP upgrade. This was not the case for the reference river, Argen, which excludes general annual effects in 2014. The lower values obtained for the two sites at the Schussen river therefore must be attributed to Schussen-specific impacts of unknown origin.

Despite the presence of endocrine disrupting chemicals (Watts et al., 2002; Mazurová et al., 2010; Schneider et al., 2015), fecundity in gammarids is also influenced by the water temperature (Pöckl, 1993a). Within the project SchussenAktivplus, at all investigated sampling sites limnological parameters were measured at every sampling time point. There were no significant differences in water temperature between the sampling sites, neither prior to nor subsequent to the WWTP upgrade (Peschke and Triebskorn, 2017). Gammarids in the field are likely exposed to a multifarious mixture of micropollutants. This mixture might adversely affect gammarid fecundity in a complex way and might possibly overwhelm potential endocrine effects by unspecific toxicity.

However, it is remarkable that, prior to the upgrade, the fecundity of gammarids at $S \quad 3$ repeatedly was significantly lower than at the upstream site $S 0$ which suggests a toxic impact of the WWTP effluent on this parameter until 2012. By upgrading the WWTP, toxic loads presumably were reduced which resulted in comparably similar fecundity indices upstream and downstream of the WWTP.

\section{Hsp70 Level}

Data for Hsp70 in general were highly variable and, thus, no statistically significant differences between the sampling sites were detected. At most, data showed a trend toward higher Hsp70 levels in gammarids from S 3 (downstream of the WWTP) compared to those from S 0 (upstream of the WWTP) and S 5 (Argen river), as well as trends to differences in Hsp70 levels depending on the year of investigation. These trends were independent of the season and visible prior and subsequent to the WWTP upgrade. This finding was corroborated by results obtained for feral fish in these rivers (Wilhelm et al., 2017). Also for them, annual variation but no significant spatial effects have been recorded.

\section{Integrity of the Macrozoobenthic Community \\ Number of Taxa and Sensitive Taxa}

The number of taxa differed between the sampling sites as well as between the situation prior and subsequent to the WWTP upgrade (Figure 5). Prior to the upgrade, a decrease in the number of taxa along the course of the river Schussen from S 0 to $S 3$ was detected in autumn. The number of taxa at sampling sites downstream of the WWTP (S 2 and S 3) was lower than upstream of the WWTP (S 0) and downstream of the SOB (S 1). The lowest number of macrozoobenthic taxa was recorded at $S$ $3,15 \mathrm{~km}$ downstream of the WWTP. After the WWTP upgrade, the number of taxa at S $0, S 1$, and S 3 was lower than prior to the upgrade, same was true for sampling site S 4 at the river Argen. This might be due to annual effects. However, at site S 2 directly downstream of the WWTP the taxa number increased after the WWTP upgrade.

Data for the macrozoobenthic community were analyzed in addition with respect to responses of taxa particularly sensitive to toxic effects according to Fauna Aquatica Austriaca (Ofenböck et al., 2010). These include several ephemeropteran 


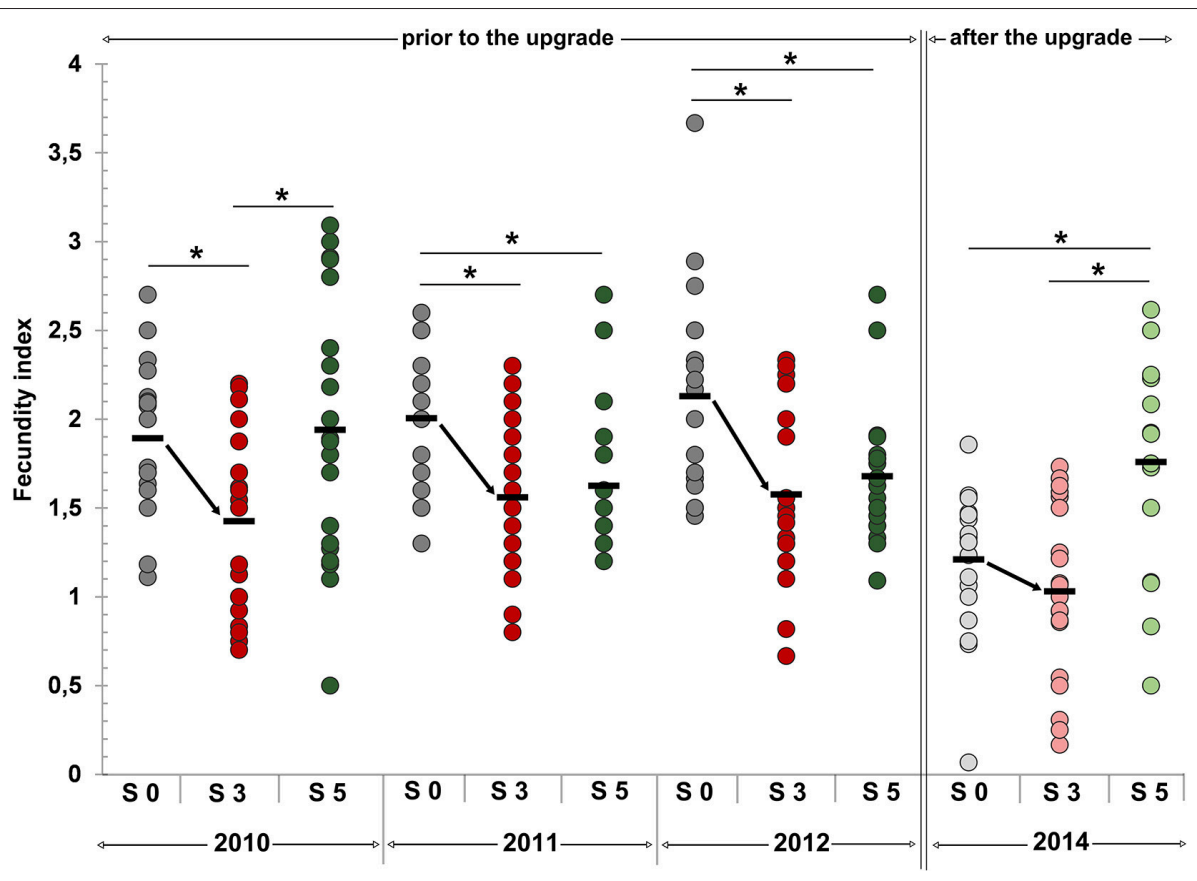

FIGURE 4 | Fecundity index of female gammarids in autumn prior to (2010-2012, dark colors) and after (2014, light colors) the wastewater treatment plant (WWTP) upgrade. Arithmetic mean is graphed as black bar. Sampling sites at the Schussen river in gray colors: S 0 upstream of the WWTP, and in red colors: S 3 downstream of the WWTP. Sampling site S 5 at the Argen river in green colors. Sampling sizes: At each sampling site per year $n=20$ breeding females. Statistically analyzed via Welch's $t$-test followed by sequential Bonferroni-Holm correction. Significant differences marked with asterisks: 2010S 0-S $3 p=0.0034$, S 3-S $5 p=0.0149$; 2011 S 0-S $3 p=0.0027$, S O-S $5 p=0.0067$; 2012 S 0-S $3 p=0.0025$, S 0-S $5 p=0.0066$; 2014 S 0-S $5 p=0.0023$, S 3-S $5 p=0.0022$. Furthermore, fecundity indices at S 0 in 2010, 2011, and 2012 were significantly higher compared to $S 0$ in 2014 ( $p=0.0125, p=0.0125, p=0.0120$ ) (not marked in the graph). Same was true for fecundity indices at S 3 in 2010, 2011, and 2012 compared to S 3 in 2014 ( $p=0.0207, p=0.0012, p=0.0014$ ) (not marked in the graph).

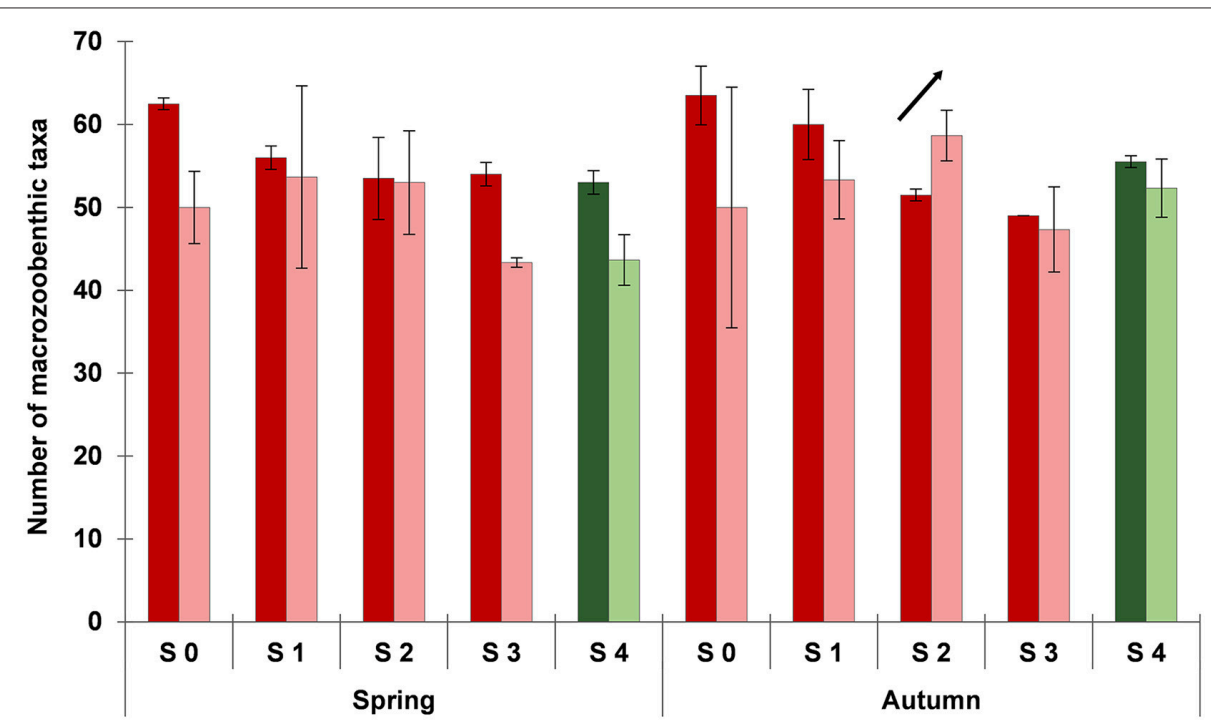

a prior to the WWTP upgrade $\square \square$ after the WWTP upgrade

FIGURE 5 | Number of macrozoobenthic taxa in spring and autumn prior to (2012 and 2013, dark colors) and after (2014, 2015, and 2016; light colors) the wastewater treatment plant (WWTP) upgrade. Data are shown as arithmetic means and standard deviations. Data for the sampling sites at the Schussen river are shown in red colors: S 0 upstream of the WWTP and upstream of the stormwater overflow basin (SOB) Mariatal, S 1 upstream of the WWTP and downstream of the SOB, S 2 directly downstream of the WWTP, S $315 \mathrm{~km}$ downstream of the WWTP; data for the sampling site S 4 at the Argen river are shown in green colors. 


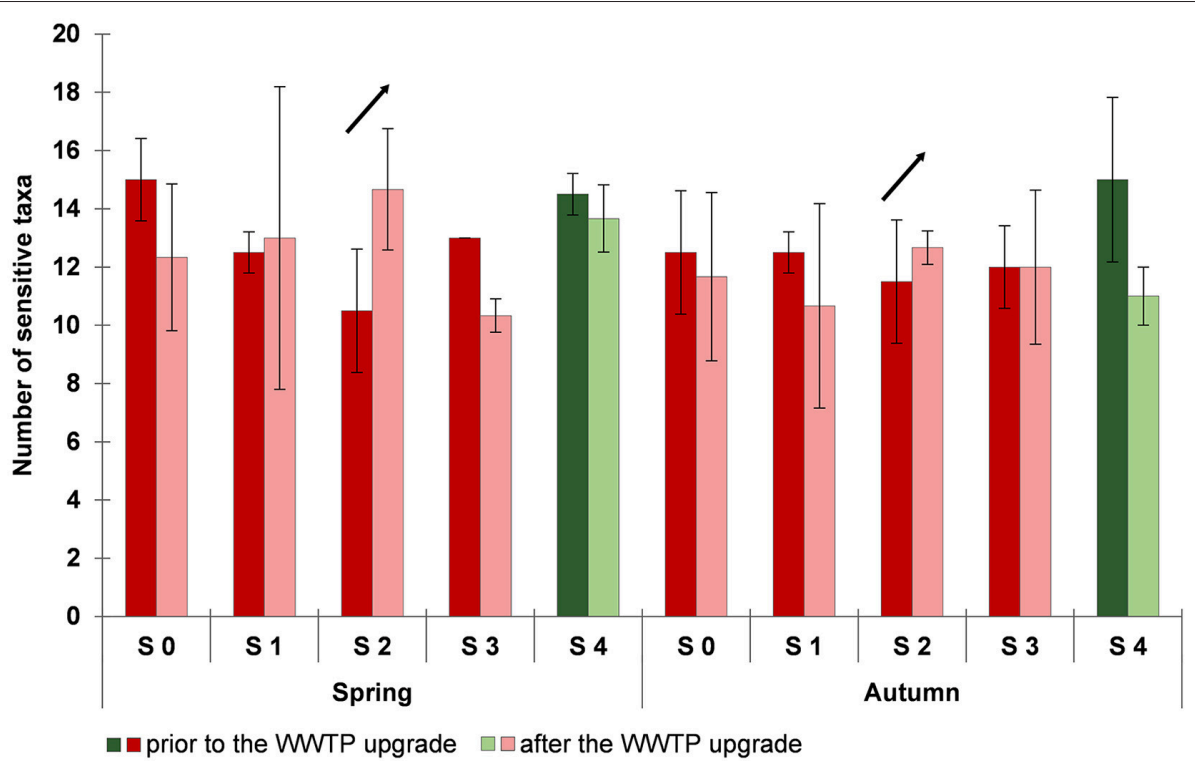

FIGURE 6 | Number of sensitive taxa in spring and autumn prior to (2012 and 2013, dark colors) and after (2014, 2015, and 2016; light colors) the wastewater treatment plant (WWTP) upgrade. Data are shown as arithmetic means and standard deviations. Data for the sampling sites at the Schussen river are shown in red colors: S 0 upstream of the WWTP and upstream of the stormwater overflow basin (SOB) Mariatal, S 1 upstream of the WWTP and downstream of the SOB, S 2 directly downstream of the WWTP, S $315 \mathrm{~km}$ downstream of the WWTP; data for the sampling site $\mathrm{S} 4$ at the Argen river are shown in green colors.
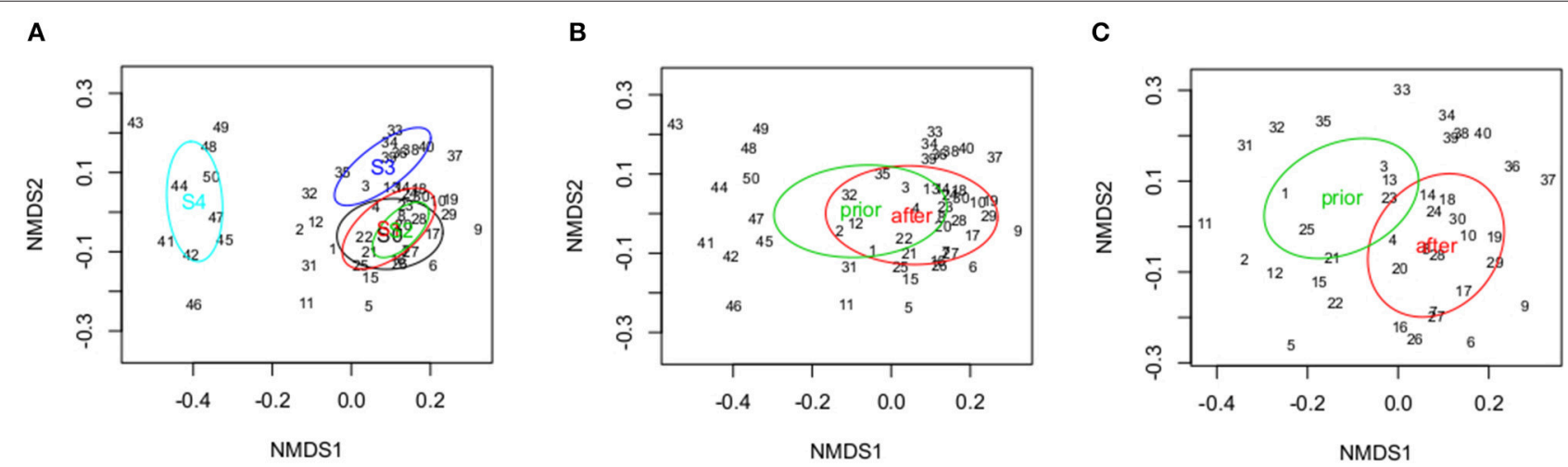

FIGURE 7 | NMDS (non-metric multidimensional scaling) for the dataset of the whole macrozoobenthic community. (A) Difference between the river Schussen (S 0, S 1, S 2, and S 3) and the river Argen (S 4). (B) NMDS including S 4 (Argen). Significant difference between the datasets prior to and after the upgrade of the WWTP. ANOSIM: $p=0.014 ; R$ statistic $=0.11$. (C) NMDS for the river Schussen solely (excluding $S 4$ ). Significant difference between the datasets prior to and after the upgrade of the WWTP. ANOSIM: $p=0.001 ; R$ statistic $=0.37$.

and plecopteran taxa, but also riffle beetles (Elmidae) like Elmis sp., Esolus sp., and Riolus sp. (Ofenböck et al., 2010; Moog et al., 2017). The number of sensitive taxa varied largely in terms of space and time at the Schussen river (Figure 6). Prior to the WWTP upgrade, less sensitive taxa were found downstream of the SOB (S 1) and downstream of the WWTP (S 2) compared to the upper sampling site (S 0 ). The lowest number of sensitive taxa was found at sampling site $S$ 2, directly downstream of the WWTP, the highest at sampling site upstream of the WWTP (S 0) and at the river Argen (S 5). After the WWTP upgrade, the number of sensitive taxa at $S 0$ and $S 4$ was lower compared to the situation prior to the upgrade. This might be due to annual effects. But the number of sensitive taxa at S 2 directly downstream of the WWTP increased considerably after the upgrade.

The data generated by ANOSIM for the whole community and the sensitive taxa datasets corroborated these results. Regarding the ANOSIM including sampling site S 4 (Argen river) differences between the river Argen ( 4 ) and the Schussen river ( $\mathrm{S} 0, \mathrm{~S} 1, \mathrm{~S} 2$, and S 3) with respect to the entire macrozoobenthic community became obvious (Figure 7A). The comparison of the community structure prior vs. subsequent to the upgrade of the WWTP showed significant differences (ANOSIM, $p=$ $0.014 ; R$ statistic $=0.11)$ (Figure 7B). Furthermore, performing 


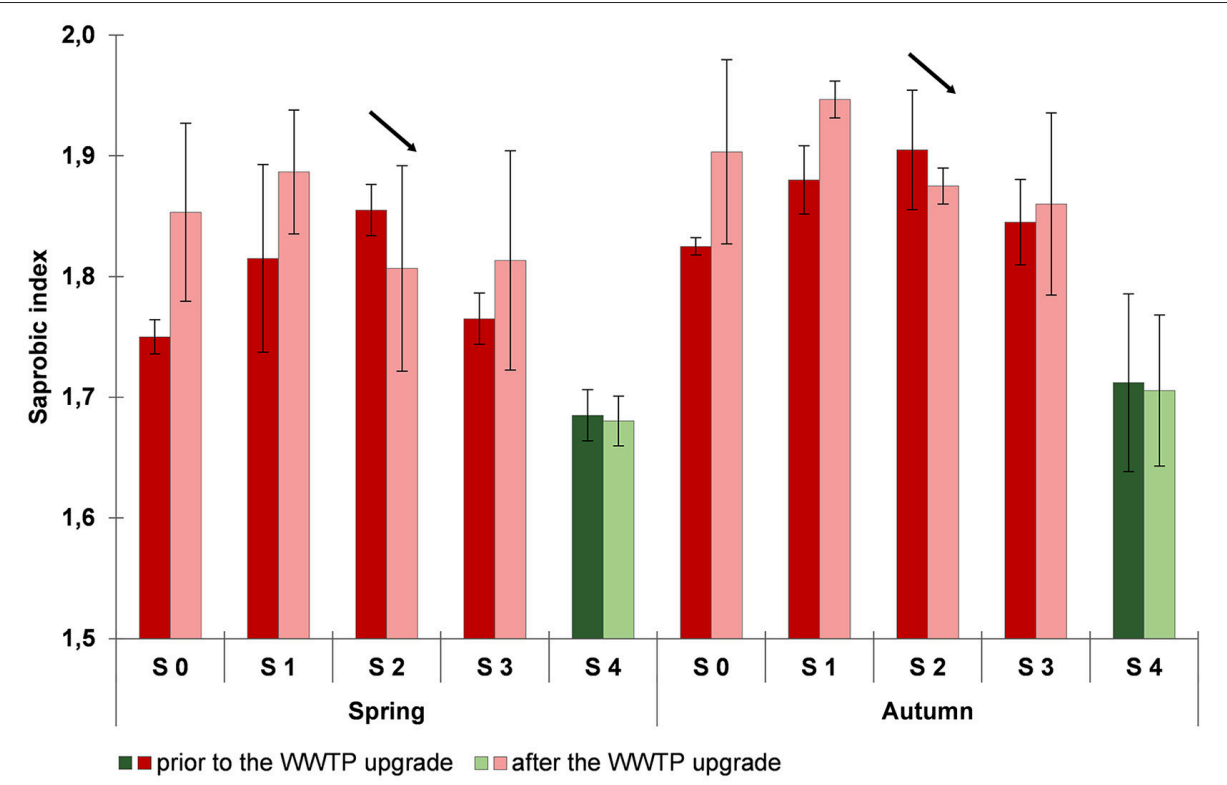

FIGURE 8 | Saprobic index in spring and autumn prior to (2012 and 2013, dark colors) and after (2014, 2015, and 2016; light colors) the wastewater treatment plant (WWTP) upgrade. Data are shown as arithmetic means and standard deviations. Data for the sampling sites at the Schussen river are shown in red colors: $\mathbf{S} 0$ upstream of the WWTP and upstream of the stormwater overflow basin (SOB) Mariatal, S 1 upstream of the WWTP and downstream of the SOB, S 2 directly downstream of the WWTP, S $315 \mathrm{~km}$ downstream of the WWTP; data for the sampling site S 4 at the Argen river are shown in green colors.

ANOSIM solely for the river Schussen (excluding sampling site $S$, Figure 7C) the difference between the situations prior to and after the upgrade of the WWTP became much more significant indicating that the effect of the upgrade was more pronounced than the natural variations observed for the river Argen dataset (S 4).

For plecopteran taxa, highly increased abundances at S 2 downstream of the WWTP after the WWTP upgrade became evident. The number of individuals of Perla abdominalis, Protonemura sp., and Leuctra fusca was almost doubled in comparison to the situation prior to the WWTP upgrade. Moreover, the highly sensitive Perla marginata was detected for the first time at sampling sites downstream of the WWTP after the WWTP upgrade. Also the number of riffle beetles (Elmidae) of the genus Elmis, Esolus, and Riolus increased notably at sampling sites downstream of the WWTP after the WWTP upgrade. In addition, Brachycentrus subnubilus (Trichoptera), as well as Epeorus assimilis, Heptagenia longicauda, and Heptagenia sulphorea (Ephemeroptera) were detected more frequently than prior to the upgrading. The occurrence of "new" taxa downstream of the WWTP after the upgrade and the increase of macrozoobenthic taxa, which was detected in every year subsequently to the upgrade, showed that the upgrade of the WWTP led to considerably positive changes in the integrity of the macrozoobenthic community. The current abundances of these "new" taxa, however, were still too low for calculating statistical differences. However, based on the observed changes that appeared within a rather short period of time, we can assume that ongoing alterations regarding the distribution of sensitive species can be statistically undermined within the next few years.

\section{Saprobic Index}

Between 2012 and 2016, prior to as well as after the WWTP upgrade, the saprobic index at all sampling sites in the Schussen river was classified as "good" [range of 1.6 to 2.1, according to WFD, (European Comission, 2000)] (Figure 8). The saprobic index at S 4 at the Argen river was lower compared to the river Schussen, hence, the water quality, in terms of nutrients, at the Argen river was comparatively better than at the river Schussen. Prior to the WWTP upgrade, the saprobic indices in the Schussen increased along the course of the river from site S 0 upstream of the WWTP to site S 1 downstream of the SOB and, further on, to site S 2 directly downstream of the WWTP. Subsequently to the WWTP upgrade, the saprobic index decreased between S 1 and S 2 and, furthermore, became lower at S 2 after the upgrade compared to the prior situation. Changes in the saprobic index are caused by changes in the abundance of several macrozoobenthic taxa. As previously discussed, the number of sensitive taxa increased downstream of the WWTP after the upgrading. In contrast, the abundance of taxa which were classified as saprobic taxa and benefit from organic matter, like the leech Erpobdella octoculata or the sludge worm Tubifex sp., decreased downstream of the WWTP after the upgrade. This indicates a slight reduction of organic substances caused by upgrading of the WWTP. Positive changes detected for sampling site S 2 did not apply to sampling site S 3 $15 \mathrm{~km}$ downstream of the WWTP. Subsequently to the WWTP upgrade, the saprobic index did not substantially differ from the situation prior to the expansion. The area around sampling site S 3 is characterized by intensive cultivation farming of hops and fruits, whereas around S 2 the agricultural use is rather moderate. In addition, the stream Schwarzach enters the 
river Schussen between S 2 and S 3. The catchment area of this tributary to the Schussen is characterized by large areas dominated by the cultivation of special crops. The abundance of sensitive species which are included in the calculation of the saprobic index can be affected by pesticides. Therefore, pesticides may induce changes with respect to the saprobic index. Sampling site S 3 might be influenced by pesticide runoff and/or manure from agricultural use which potentially has overwhelmed the positive changes achieved at sampling site $S 2$ by the WWTP upgrade.

\section{CONCLUSION}

Our investigations on gammarids showed that the sex ratio of gammarids sampled in the river Schussen downstream of the WWTP was significantly shifted toward females in spring and summer before the WWTP had been upgraded. Furthermore, the fecundity index of breeding females downstream of the WWTP was lower than at the upstream site. After the installation of the additional purification step, the situation has considerably changed. Fecundity indices of breeding females have been found to be comparably similar upstream and downstream of the WWTP. Three and four years after the upgrading, changes concerning the sex ratio in gammarids became obvious: the sex ratio in the gammarid population residing downstream of the WWTP was no longer shifted in favor of females. Concomitant chemical analyses (Scheurer et al., 2017a,b) have revealed such substances to be eliminated by the additional treatment step which could have caused these effects. Our investigations of the macrozoobenthic community integrity mirrored the changes found in our studies with gammarids. Prior to the upgrading, the total number of macrozoobenthic taxa and the number of sensitive taxa had been found to be lower downstream of the WWTP than upstream of it. After the installation of the additional treatment step, a distinctive increase of the total numer of taxa and the number of sensitive taxa was apparent at the sampling site downstream of the WWTP. Therefore, the upgrade with the powdered activated carbon step was shown to be highly efficient in reducing the toxicity of the WWTP effluent and, thus, to restore invertebrate health and improve the macrozoobenthic community integrity within a rather short period of time, and, consequently, to sustainably protect aquatic ecosystems.

\section{AUTHOR CONTRIBUTIONS}

KP: sampling and analysis of gammarids and writing the manuscript. YC: statistical analysis of macrozoobenthic dataset. H-RK: feedback and support to analysis and draft manuscript. KW: sampling of macrozoobenthos. RT: project leader of the

\section{REFERENCES}

Adámek, Z., Orendt, C., Wolfram, G., and Sychra, J. (2010). Macrozoobenthos response to environmental degradation in a heavily modified stream: case study the Upper Elbe River, Czech Republic. Biologia 65, 527-536. doi: 10.2478/s11756-010-0043-5 project SchussenAktivplus, feedback and support to analysis, major revisions on draft manuscript.

\section{FUNDING}

Studies with gammarids were funded by the MTU Umweltstiftung Bodensee. The first part of the project, SchussenAktiv (2010-2012), was funded by the Ministry for Environment, Nature Conservation and Transport Baden-Württemberg (UM), and the foundation Nature and Environment of the Regional State Bank Baden-Württemberg (LBBW). The project SchussenAktivplus was funded by the Federal Ministry for Education and Research (BMBF) and cofunded by the Ministry of the Environment, Climate Protection and the Energy Sector, Baden-Württemberg. SchussenAktivplus was part of the BMBF action plan Sustainable water management $(\mathrm{NaWaM})$ integrated in the BMBF frame program Research for sustainable development FONA. It was part of the funding measure Risk Management of Emerging Compounds and Pathogens in the Water Cycle (RiSKWa). Contract period: January 2012 to June 2016, funding number: 02WRS1281J. Jedele \& Partner GmbH, Ökonsult GbR, the city of Ravensburg, the AZV Mariatal and the AV Unteres Schussental have financially contributed to the project. Open access publishing was funded by Deutsche Forschungsgemeinschaft and Open Access Publishing Fund of University of Tübingen.

\section{ACKNOWLEDGMENTS}

The authors would like to thank the institutions that have given financial support: MTU Umweltstiftung Bodensee; Ministry for Environment, Nature Conservation and Transport BadenWürttemberg (UM); foundation Nature and Environment of the Regional State Bank Baden-Württemberg (LBBW); Federal Ministry for Education and Research (BMBF); Ministry of the Environment, Climate Protection and the Energy Sector, BadenWürttemberg. Many thanks go also to Jedele \& Partner GmbH, Ökonsult GbR, the city of Ravensburg, the AZV Mariatal and the AV Unteres Schussental who financially contributed to the project. The authors are also very grateful to the Animal Physiological Ecology group of Tübingen University, especially to J. Burmester, H. Eckstein, M. Hermann, K. Reitter, and D. Schmidt for excellent work within their final theses; and to A. Dieterich, K. Bader, A. Elsässer, J. Geburzi, A. Henneberg, S. Jacob, S. Krais, D. Maier, H. Schmieg, C. Schulz, L. Schuster, M. Schweizer, S. Schwarz, K. Vincze, S. Wilhelm, M. Wolter, and M. Ziegler for great help in the lab and during the field work. The authors also acknowledge support by Deutsche Forschungsgemeinschaft and Open Access Publishing Fund of University of Tübingen.

Berenzen, N., Kumke, T., Schulz, H. K., and Schulz, R. (2005). Macroinvertebrate community structure in agricultural streams: impact of runoffrelated pesticide contamination. Ecotoxicol. Environ. Saf. 60, 37-46. doi: 10.1016/j.ecoenv.2003.10.010

Bonzini, S., Finizio, A., Berra, E., Forcella, M., Parenti, P., and Vighi, M. (2008). Effects of river pollution on the colonisation of 
artificial substrates by macrozoobenthos. Aquatic Toxicol. 89, 1-10. doi: 10.1016/j.aquatox.2008.05.008

Borowsky, B. (1984). The use of the males' gnathopods during precopulation in some gammaridean amphipods. Crustaceana 47, 245-250. doi: 10.1163/156854084X00504

Bradford, M. M. (1976). A rapid and sensitive method for the quantitation of microgram quantities of protein utilizing the principle of protein-dye binding. Anal. Biochem. 72, 248-254. doi: 10.1016/0003-2697(76)90527-3

Brehm, J., and Meijering, M. P. (1996) Fließgewässerkunde - Einführung in die Ökologie der Quellen, Bäche und Flüsse. Wiesbaden: Quelle und Meyer Verlag.

Bundschuh, M., and Schulz, R. (2011a). Ozonation of secondary treated wastewater reduces ecotoxicity to Gammarus fossarum (Crustacea; Amphipoda): are loads of (micro)pollutants responsible? Water Res. 45, 3999-4007. doi: 10.1016/j.watres.2011.05.007

Bundschuh, M., and Schulz, R. (2011b). Population response to ozone application in wastewater: an on-site microcosm study with Gammarus fossarum (Crustacea: Amphipoda). Ecotoxicology 20, 466-473. doi: 10.1007/s10646-011-0599-Z

Daughton, C. G., and Ternes, T. A. (1999). Pharmaceuticals and personal care products in the environment: agents of subtle change? Environ. Health Perspect. 107, 907-938. doi: 10.1289/ehp.99107s6907

De-La-Ossa-Carretero, J. A., Del-Pilar-Ruso, Y., Giménez-Casalduero, F., Sánchez-Lizaso, J. L., and Dauvin, J. C. (2012). Sensitivity of amphipods to sewage pollution. Estuar. Coast. Shelf Sci. 96, 129-138. doi: 10.1016/j.ecss.2011.10.020

Di Lascio, A., Rossi, L., Carlino, P., Calizza, E., Rossi, D., and Costantini, M. L. (2013). Stable isotope variation in macroinvertebrates indicates anthropogenic disturbance along an urban stretch of the river Tiber (Rome, Italy). Ecol. Indic. 28, 107-114. doi: 10.1016/j.ecolind.2012.04.006

European Comission (2000). Directive 2000/60/EC of the European Parliament and of the Council of 23 October 2000 Establishing a Framework for Community Action in the Field of Waterpolicy. Official Journal of the European Communities.

Giebner, S., Ostermann, S., Straskraba, S., Oetken, M., Oehlmann, J., and Wagner, M. (2018). Effectivity of advanced wastewater treatment: reduction of in vitro endocrine activity and mutagenicity but not of in vivo reproductive toxicity. Environ. Sci. Pollut. Res. 25, 3965-3976. doi: 10.1007/s11356-016-7540-1

Gross, M. Y., Maycock, D. S., Thorndyke, M. C., Morritt, D., and Crane, M. (2001). Abnormalities in sexual development of the amphipod Gammarus pulex (L.) found below sewage treatment works. Environ. Toxicol. Chem. 20, 1792-1797. doi: $10.1002 /$ etc. 5620200824

Haase, P., Sundermann, A., and Schindehütte, K. (2004). Informationstext zur Operationellen Taxaliste als Mindestanforderung an die Bestimmung von Makrozoobenthosproben aus Fließgewässern zur Umsetzung der EUWasserrahmenrichtlinie in Deutschland. Forschungsinstitut Senckenberg, Abteilung für Limnologie und Naturschutzforschung. Available online at: http://www.fliessgewaesserbewertung.de/download/bestimmung/ (accessed May 09, 2019)

Henneberg, A., Bender, K., Blaha, L., Giebner, S., Kuch, B., Köhler, H.R., et al. (2014). Are in vitro methods for the detection of endocrine potentials in the aquatic environment predictive for in vivo effects? Outcomes of the projects SchussenAktiv and SchussenAktivplus in the Lake Constance area, Germany. PloS ONE 9:e98307. doi: 10.1371/journal.pone.00 98307

Henneberg, A., and Triebskorn, R. (2015). Efficiency of advanced wastewater treatment technologies for the reduction of hormonal activity in effluents and connected surface water bodies by means of vitellogenin analyses in rainbow trout (Oncorhynchus mykiss) and brown trout (Salmo trutta f. fario). Environ. Sci. Europe 27:22. doi: 10.1186/s12302-015-0056-3

Kuch, B. (2017). "Technologiebewertung: E-Screen Assay," in Weitergehende Abwasserreinigung: Ein wirksames und Bezahlbares Instrument zur Verminderung von Spurenstoffen und Keimen im Wasserkreislauf, eds R. Triebskorn (Tübingen: Eberhard Karls Universität Tübingen), 210-217.

Ladewig, V., Jungmann, D., Köhler, H.-R., Schirling, M., Triebskorn, R., and Nagel, R. (2006). Population structure and dynamics of Gammarus fossarum (Amphipoda) upstream and downstream from effluents of sewage treatment plants. Arch. Environ. Contam. Toxicol. 50, 370-383. doi: 10.1007/s00244-005-7039-0
Langmaier, S. (2006). Ökologische Daten zum Vorkommen von SteinfliegenLarven (Insecta: Plecoptera) im Bundesland Salzburg, Österreich. Mitteilungen aus dem Haus der Natur Salzburg.

Luo, Y., Guo, W., Ngo, H. H. Nghiem, L. D., Hai, F. I., Zhang, J., et al. A review on the occurrence of micropollutants in the aquatic environment and their fate and removal during wastewater treatment. Sci. Tot. Environ. (2014) 473-474, 619-641. doi: 10.1016/j.scitotenv.2013.12.065

Maier, D., Benisek, M., Blaha, L., Dondero, F., Giesy, J. P., Köhler, H.-R., et al. (2016). Reduction of dioxin-like toxicity in effluents by additional wastewater treatment and related effects in fish. Ecotoxicol. Environ. Saf. 132, 47-58. doi: 10.1016/j.ecoenv.2016.04.036

Maier, D., Blaha, L., Giesy, J. P., Henneberg, A., Köhler, H.-R., Kuch, B., et al. (2015). Biological plausibility as a tool to associate analytical data for micropollutants and effect potentials in wastewater, surface water, and sediments with effects in fishes. Water Res. 72, 127-144. doi: 10.1016/j.watres.2014.08.050

Mazurová, E., Hilscherová, K., Šídlová-Štěpánková, T., Köhler, H.-R., Triebskorn, R., Jungmann, D., et al. (2010). Chronic toxicity of contaminated sediments on reproduction and histopathology of the crustacean Gammarus fossarum and relationship with the chemical contamination and in vitro effects. J. Soils Sediments 10, 423-433. doi: 10.1007/s11368-009-0166-x

Meijering, M. P., and Pieper, H. G. (1982). Die Indikatorbedeutung der Gattung Gammarus in Fließgewässern. Decheniana-Beihefte.

Moog, O., Graf, W., Janecek, B., and Ofenböck, T. (2017). “Sensitive taxa," in Fauna Aquatica Austriaca, eds O. Moog and A. Hartmann (Wien: Bundesministerium für Land- und Forstwirtschaft, Umwelt und Wasserwirtschaft Österreich), 1-5.

Ofenböck, T., Moog, O., Hartmann, A., and Stubauer, I. (2010). Leitfaden zur Erhebung der Biologischen Qualitätselemente, Teil A2Makrozoobenthos. Bundesministerium für Land-und Forstwirtschaft. Umwelt und Wasserwirtschaft.

Peschke, K., Geburzi, J., Köhler, H.-R., Wurm, K., and Triebskorn, R. (2014). Invertebrates as indicators for chemical stress in sewage-influenced stream systems: toxic and endocrine effects in gammarids and reactions at the community level in two tributaries of Lake Constance, Schussen and Argen. Ecotoxicol. Environ. Saf. 106, 115-125. doi: 10.1016/j.ecoenv.2014. 04.011

Peschke, K., and Triebskorn, R. (2017). “Auswirkungen des ausbaus der kläranlage langwiese auf das ökosystem der schussen: limnologische analytik," in Weitergehende Abwasserreinigung: Ein wirksames und bezahlbares Instrument zur Verminderung von Spurenstoffen und Keimen im Wasserkreislauf, ed R. Triebskorn (Tübingen: Eberhard-Karls Universität Tübingen), 248-249.

Pöckl, M. (1993a). Beitrage zur Ökologie des Bachflohkrebses (Gammarus fossarum) und Flussflohkrebses (Gammarus roeseli). National Museum.

Pöckl, M. (1993b). Reproductive potential and lifetime potential fecundity of the freshwater amphipods Gammarus fossarunt and G. roeseli in Austrian streams and rivers. Freshw. Biol. 30, 73-91. doi: 10.1111/j.1365-2427.1993.tb00790.x

Pöckl, M., and Humpesch, U. H. (1990). Intra- and inter-specific variations in egg survival and brood development time for Austrian populations of Gammarus fossarum and G. roeseli (Crustacea: Amphipoda). Freshw. Biol. 23, 441-455. doi: 10.1111/j.1365-2427.1990.tb00286.x

Pöckl, M., Webb, B. W., and Sutcliffe, D. W. (2003). Life history and reproductive capacity of Gammarus fossarum and G. roeseli (Crustacea: Amphipoda) under naturally fluctuating water temperatures: a simulation study. Freshw. Biol. 48, 53-66. doi: 10.1046/j.1365-2427.2003.00967.x

Scheurer, M., Richter, D., Sacher, F. (2017a). "Spurenstoffe: anlagenbewertung," in Weitergehende Abwasserreinigung: Ein wirksames und Bezahlbares Instrument zur Verminderung von Spurenstoffen und Keimen im Wasserkreislauf, ed R. Triebskorn (Tübingen: Eberhard-Karls Universität Tübingen), 161-181.

Scheurer, M., Richter, D., and Sacher, F. (2017b). Spurenstoffe: auswirkungen auf das gewässer," in Weitergehende Abwasserreinigung: Ein wirksames und Bezahlbares Instrument zur Verminderung von Spurenstoffen und Keimen im Wasserkreislauf, ed R. Triebskorn (Tübingen: Eberhard-Karls Universität Tübingen), 250-267.

Schirling, M., Jungmann, D., Ladewig, V., Ludwichowski, K.-U., Nagel, R., Köhler, H.-R., et al. (2005a). Bisphenol A in artificial indoor streams: II. Stress response and gonad histology in Gammarus fossarum (Amphipoda). Ecotoxicology 15, 143-156. doi: 10.1007/s10646-005-0044-2 
Schirling, M., Jungmann, D., Ladewig, V., Nagel, R., Triebskorn, R., and Köhler, H.-R. (2005b). Endocrine effects in Gammarus fossarum (Amphipoda): influence of wastewater effluents, temporal variability, and spatial aspects on natural populations. Arch. Environ. Contam. Toxicol. 49, 53-61. doi: 10.1007/s00244-004-0153-6

Schneider, I., Oehlmann, J., and Oetken, M. (2015). Impact of an estrogenic sewage treatment plant effluent on life-history traits of the freshwater amphipod Gammarus pulex. J. Environ. Sci. Health A Tox. Hazard. Subst. Environ. Eng. 50, 272-281. doi: 10.1080/10934529.2015.981114

Schwab, H. (1995). Süßwassertiere: Ein Ökologisches Bestimmungsbuch. Stuttgart: Ernst Klett Verlag.

Schwoerbel, J. (1999). Einführung in die Limnologie. Stuttgart: Gustav Fischer Verlag.

Sures, B. (2008). Environmental parasitology. Interactions between parasites and pollutants in the aquatic environment. Parasite 15, 434-438. doi: $10.1051 /$ parasite/2008153434

Sures, B., and Radszuweit, H. (2007). Pollution-induced heat shock protein expression in the amphipod Gammarus roeseli is affected by larvae of Polymorphus minutus (Acanthocephala). J. Helminthol. 81, 191-197. doi: 10.1017/S0022149X07751465

Thellmann, P., Greiner-Perth, K., Jacob, S., Knoll, M., Schäfer, M., Stängle, M., et al. (2017). Does waste water treatment plant upgrading with powdered activated carbon result in reduced water and sediment toxicity of the receiving stream? Int. J. Water Wastew. Treat. 3, 1-9 doi: 10.16966/2381-5299.141

Triebskorn, R. (ed). (2017). Weitergehende Abwasserreinigung: Ein Wirksames und Bezahlbares Instrument zur Verminderung von Spurenstoffen und Keimen im Wasserkreislauf. Eberhard-Karls Universität Tübingen.

Triebskorn, R., Amler, K., Blaha, L., Gallert, C., Giebner, S., Güde, H., et al. (2013a). SchussenAktivplus: reduction of micropollutants and of potentially pathogenic bacteria for further water quality improvement of the river Schussen, a tributary of Lake Constance, Germany. Environ. Sci. Europe 25, 1-9. doi: 10.1186/2190-4715-25-2

Triebskorn, R., Blaha, L., Engesser, B., Güde, H., Hetzenauer, H., Henneberg, A., et al. (2013b). SchussenAktiv-Eine Modellstudie zur Effizienz der Reduktion der Gehalte an Anthropogenen Spurenstoffen Durch Aktivkohle in Kläranlagen: Expositions-und Effektmonitoring vor Inbetriebnahme der Adsorptionsstufe auf der Kläranlage Langwiese des AZV Mariatal, Ravensburg. Korrespondenz Wasserwirtschaft (Hennef) 427-437.
Triebskorn, R., and Hetzenauer, H. (2012). Micropollutants in three tributaries of Lake Constance, Argen, Schussen and Seefelder Aach: a literature review. Environ. Sci. Europe 24, 1-24. doi: 10.1186/2190-47 15-24-8

Villa, S., Di Nica, V., Bellamoli, F., Pescatore, T., Ferrario, C., Finizio, A., et al. (2018). Effects of a treated sewage effluent on behavioural traits in Diamesa cinerella and Daphnia magna. J. Limnol. 77, 121-130 doi: 10.4081/jlimnol. 2018.1760

Vincze, K., Scheil, V., Kuch, B., Köhler, H.-R., and Triebskorn, R. (2015). Impact of wastewater on fish health: a case study at the Neckar River (Southern Germany) using biomarkers in caged brown trout as assessment tools. Environ. Sci. Pollut. Res. 22, 11822-11839. doi: 10.1007/s11356-0154398-6

Watts, M. M., Pascoe, D., and Carroll, K. (2002). Population responses of the freshwater amphipod Gammarus pulex (L.) to an environmental estrogen, 17a-ethinylestradiol. Environ. Toxicol. Chem. 21, 445-450. doi: 10.1002/etc. 5620210230

Welton, J. S. (1979). Life-history and production of the amphipod Gammarus pulex in a Dorset chalk stream. Freshw. Biol. 9, 263-275. doi: 10.1111/j.1365-2427.1979.tb01508.x

Wilhelm, S., Henneberg, A., and Triebskorn, R. (2017). "Auswirkungen des Ausbaus der Kläranlage Langwiese auf das Öko Wilhelm et al., 2017system der Schussen: Stressproteinanalysen," in Weitergehende Abwasserreinigung: Ein wirksames und Bezahlbares Instrument zur Verminderung von Spurenstoffen und Keimen im Wasserkreislauf, ed Triebskorn, R (Tübingen: Eberhard-Karls Universität Tübingen, Universitätsbibliothek), 306-310.

Conflict of Interest Statement: The authors declare that the research was conducted in the absence of any commercial or financial relationships that could be construed as a potential conflict of interest.

Copyright (๑ 2019 Peschke, Capowiez, Köhler, Wurm and Triebskorn. This is an open-access article distributed under the terms of the Creative Commons Attribution License (CC BY). The use, distribution or reproduction in other forums is permitted, provided the original author(s) and the copyright owner(s) are credited and that the original publication in this journal is cited, in accordance with accepted academic practice. No use, distribution or reproduction is permitted which does not comply with these terms. 